\title{
Sluiting in die drama
}

\author{
Nancy-Anne Anderson \\ Departement Algemene Literatuurwetenskap \\ Universiteit van die Oranje-Vrystaat \\ BLOEMFONTEIN
}

\begin{abstract}
Abstraet
Closure in drama

In this article closure is investigated as a strategy in dramatic communication. After explicating the relevant terminology for purposes of intersubjectivity, closure in drama is explained by way of logical analysis. In conclusion this argumentation is empirically tested by confronting it with the independent reading results of selected critics.
\end{abstract}

\section{Inleiding}

Die strategie van tekssluiting en die lesersverwagting ten opsigte van die slot is al vanuit verskillende perspektiewe deur teoretici ondersoek. Verskeie van dié studies karakteriseer sluiting in 'n bepaalde genre, byvoorbeeld Torgovnick (1981) se Closure in the Novel, Miller (1989) se Narrative and Its Discontents: Problems of Closure in the Traditional Novel, en Herrnstein Smith (1968) se Poetic Closure: a Study of How Poems End. Die gebrek aan studies wat tekssluiting in die dramagenre ondersoek, is egter opvallend en die enkele ondersoeke wat wel hieroor handel, behels meestal die bespreking van 'n spesifieke dramateks se slot.

Dit is teen dié agtergrond dat ek sluiting in die drama wil verklaar en wel, as vertrekpunt, op logiese gronde. $\mathrm{Na}$ afloop van die karakterisering van dramatiese sluiting sal empiriese steun vir die argument aangevoer word aan die hand van enkele reeds gepubliseerde leesverslae. Die fokus val dus nie op die bespreking van sluiting op teksvlak nie, maar op die analise van sluiting op sisteemvlak tydens dramatiese kommunikasie wat, uiteraard, optimaal funksioneer. So 'n benadering bring mee dat sluiting in die drama, die narratief en die poësie op 'n gemeenskaplike basis vergelyk word en die onderskeidende aard van elk uitgespel word. So 'n benadering bemoontlik weer 'n verskeidenheid van navorsingsprojekte wat aspekte van generiese sluiting in verskillende periodes en nasionale literature op 'n sistematies konsekwente manier ondersoek, dit wil sê in terme van dieselfde wetenskaplike begripskader. Implementering van sodanige ondersoekraam sal die verklaringspotensiaal verhoog van 'n studie soos "The search for new endings: the theatre in search of a fix, part iii" (Corrigan, 1984) 
waarin die uiteenlopende aard van dramatiese sluiting tydens verskillende periodes geïdentifiseer word. Allereers ekspliseer ek egter terminologie wat verband hou met tekssluiting ter wille van intersubjektiwiteit.

\section{Oop einde, geslote einde en die leë plek in die tekseinde}

As uitgangspunt geld die (semioties-strukturalistiese) veronderstelling dat die literêre teks betekenisvol is danksy organisasie, dit wil sê die tekseinde is gestruktureer as geslote of oop einde, of as woordleegte. Dat die oop einde nie toevallig "oop" is nie, word onder meer deur Lodge (1981:154) bevestig: "The open ending, like the closed ending, still, after all, asserts the existence of an order, rather than a plurality of orders, or an absence of order". Daar word dus nie met Hillis Miller (1978:5) saamgestem as hy strukturering van die tekseinde ontken nie en van mening is dat die literêre teks in beginsel onvolledig is: "The aporia of ending arises from the fact that it is impossible ever to tell whether a given narrative is complete. If the ending is thought of as a tying up in a careful knot, this knot could always be untied again by the narrator or by further events, disentangled or explicated again".

Eweneens word daar van Eco (1989:12) verskil as hy sogenaamde "works in movement" ('n variant wat hy onderskei binne die kategorie "open works") karakteriseer as tekste waarin "unplanned or physically incomplete structural units" voorkom. Volgens Eco is sommige tekens onbeplan of onvolledig, en as sodanig nie doelbewus in die teks georganiseer nie. Indien die standpunt geldig sou wees, kan Eco (1989:19) nie argumenteer dat voltooiing van die "works of movement" enersyds "the possibility of numerous different personal interventions" toelaat, maar andersyds nie "an amorphous invitation to indiscriminate participation" behels nie. Slegs wanneer prinsipieel aanvaar word dat alle tekstekens gestruktureer is, en nie toevallig of onbeplan in die teks voorkom nie, kan geargumenteer word dat die invul van sodanige tekens nie arbitrêr geskied nie.

Teen die agtergrond van die veronderstelde gestruktureerdheid van alle tekens in die literêre teks word vervolgens onderskei tussen die oop einde en die leë plek wat tydens tekssluiting funksioneer. Hierdie onderskeid is nodig aangesien op arbitrêre wyse van die oop einde gepraat word en 'n oop einde nie noodwendig die aanwesigheid van 'n woordleegte impliseer nie.

In Equivocal Endings in Classic American Novels verwys Rowe (1988:6) na die veelvoudige maniere waarop na oop eindes verwys word, en hy kom tot dié gevolgtrekking: "Although connotations vary, there is a consensus that an open ending signifies an openness to experience as indeterminate and unpredictable - a flux which will never yield a permanent or stable sense of self'. Dresden (1980: 38) se formulering lui: "(Het) einde streeft er niet naar het voorafgaande voor 
goed en zo nauwkeurig mogelijk vast te leggen maar wil wegen naar de toekomst open houden en doen uitkomen dat dit einde voorlopig en feitelijk toevallig is". Die oop einde laat by die leser 'n onsekerheid ten opsigte van die verloop van die tekswêreld en laat nie finale en enkelvoudige betekenistoekenning toe nie. Lodge (1981:154) som dit só op: "With the acceptance of the open ending in modem fiction, the ending which is satisfying but not final, the recognition of ambiguity or uncertainty in experience is institutionalised as form".

Die oop einde word gekontrasteer met die geslote einde, met die "unity of works which seem to complete a particular pattern, to cover a specific period of time, for instance, as with Joyce's Ulysses or Woolf's Mrs Dalloway, or to 'enclose' the action of a work by a sudden time-shift - as at the end of Keats's 'The Eve of St. Agnes'" (Hawthom 1987:44). Die oop einde van 'n teks, moet 'n mens onthou, funksioneer teen die agtergrond van die lesersverwagting dat die teks wel definitiewe sluiting sal bewerkstellig. Dit verklaar Forster (1949) se standpunt dat 'n huwelik of die dood tradisioneel as die algemeenste manier van tekssluiting voorkom. Volgens Kermode (1979:53-54) word die leser gerig deur 'n "prior expectation of consonance, the assumption that as readers we have to complete something capable of completion". Hy wys daarop dat Shklovsky die metaforiese lees van tekseindes toeskryf aan die leser se verwagting van en wens vir 'n bevredigende slot:

It was he who showed that we can derive the sense of fulfilled expectation, of satisfactory closure, from texts that actually do not provide what we ask, but give us instead something that, out of pure desire for completion, we are prepared to regard as a metaphor or synecdoche for the ending that is not there: a description of the weather or the scenery, he says, will do, say the rain at the end of Hemingway's Farew'ell to Arms, or the river at the end of Matthew Arnold's Sohrah and Rushum (Kermode, 1979:65).

Of sluiting bewerkstellig word deur 'n letterlike of 'n metaforiese lees van die verbaal aanwesige woorde, en of 'n oop einde die resultaat is van slotwoorde se veelvoudige betekenismoontlikhede, dit verskil van sluiting by wyse van die leë plek.

Die lee plek word gekarakteriseer aan die hand van sy onderskeidende tekenaard en die logiese implikasies daarvan. Die woordleegte behels nie - soos ander tekstekens - 'n verbaal aanwesige woord of teksteken nie, maar veronderstel 'n nie-verbale teksteken. Dié nie-verbale teken is soos alle tekstekens gestruktureer en daarom betekenisvol. As die binariteit van tekstekens aanvaar word, dit wil sê dat 'n tekenl uit 'n betekenaar en 'n betekende bestaan, dan behels die leë plek 'n verbaal afwesige betekenaar wat 'n betekende impliseer. Die leser word die taak gestel om die verbaal afwesige betekenaar in te vul, dit wil sê letterlik onder woorde te bring. 
Die invul van die leë plek geskied egter nie arbitrêr nie. Soos alle tekstekens is ook die woordleegte in terme van die sintagmatiese en paradigmatiese asse gestruktureer. Danksy sintagmatiese organisasie kom die leë plek op 'n bepaalde en dus identifiseerbare plek in die teks voor. Die seleksie-as skryf voor binne watter paradigma of paradigmas dié teksteken funksioneer en die paradigmatiese relasies medebepaal die toekenning van betekenis aan die leë plek.

Die onderskeid tussen 'n oop einde en sluiting by wyse van 'n leë plek berus dus op die verskil in tekenaard: die oop einde behels 'n verbale betekenaar met veelduidige of metaforiese betekendes, terwyl die leë plek 'n verbaal afwesige betekenaar veronderstel wat 'n betekende of betekendes in die teks kommunikeer. Sluiting deur middel van 'n leë plek betrek die leser optimaal aangesien hy/sy self die verbaal afwesige betekenaar moet invul.

\section{Sluiting in die drama}

Ter wille van die doeleindes van dié analise, aanvaar ek die genremodel waarvolgens die funksie van dramatiese kommunikasie hom onderskei van dié van poëtiese en narratiewe kommunikasie deurdat dramatiese kommunikasie die ontvanger konfronteer met 'n keuse tussen alternatiewe moontlikhede (Strydom, 1996). Die verskillende moontlikhede wat die leser self moet beoordeel, word deur die karakters verwoord, en daarom kom karakters met verskillende standpunte of perspektiewe teenoor mekaar te staan in die dialoog. Serpieri (1989:59) verduidelik:

If drama is institutionally based on antithesis, the characters cannot share the same propositional attitude with regard to a state of affairs, insofar as they must actualise a clash of 'worlds' which always manifests itself in tactics of reciprocal influence. Unable to agree, but forced to coexist within a story or a situation, that has its origin in the very fact that they disagree, each of the characters tries to assert his own world (or that of a group of characters that he represents) by means of illocutionary acts.

Die dramagenre veronderstel dus ' $n$ botsing van logiese argumente of standpunte wat deur karakters verteenwoordig word. Die opponerende standpunte word direk aan die leser voorgehou sonder die invloed van ' $n$ bemiddelingsinstansie. Die leser word gedwing om self tussen alternatiewe moontlikhede te kies in dramas "(which) force the audience to reflect on the irresolvability of the dilemmas and the inadequacy of conventional solutions" (Gellrich, 1988:228).

Indien aanvaar word dat 'n oop einde meervoudige betekenismoontlikhede behels en onsekerheid by die leser teweegbring oor die verdere verloop, dan word die drama, wat die leser met botsende perspektiewe konfronteer, in beginsel gekenmerk deur 'n oop einde. Schmidt (1992:9) haal Hauptmann aan in diè 
verband: "True drama is basically endless. It is an eternal inner struggle without resolution. At the moment of resolution, drama breaks off".

In aansluiting hierby is Tarvin $(1990: 21,24)$ se argument dat verskeie tragedies nie gekenmerk word deur die "concept of a restoration of order and a terminal calm regularly marking the end of tragedies" nie, maar dat hulle eerder terselfdertyd "at peace" en "not at peace" sluit. Volgens Tarvin (1990:22) eindig dramas soos The Persians, Prometheus Bound, Trachiniae, The Trojan Women, The Bacchantes, Doctor Faustus en Troilus and Cressida "not (...) with a period, or even a question mark, but rather with an ellipses, and the terminal effect is one of irresolution and continued tension".

Die vraag ontstaan nou of die kenmerkende oop einde van die drama toegeskryf kan word aan die aanwesigheid van 'n leë plek, dit is 'n verbaal afwesige betekenaar wat stnuktureel aktief is. Die leser word aan die einde van die teks soos tydens die verloop van die teks - steeds met verskillende alternatiewe gekonfronteer: op implisiete wyse, met behulp van leë plekke. Die dilemma van kies word nie soos in die narratief deur die verteller opgelos nie, maar aan die leser self oorgelaat. 'n Leë plek met die funksie om alternatiewe te opponeer, kom dus in beginsel aan die einde van die drama voor. Die logiese konsekwensie van die dramatiese sisteem se konfrontasie-beginsel is met ander woorde dat die leser aan die einde voor die keuse tussen opponerende standpunte gestel word deur die woordleegte.

'n Keuse tussen botsende persepsies wat verskillende karakters verteenwoordig, sal die mees voor die hand liggende manifestasie wees van die woordleegte tydens tekssluiting. 'n Karakter se slotspreekbeurt kan egter opponerende alternatiewe impliseer en danksy die funksionering van 'n leë plek moet die leser self dié alternatiewe teen mekaar opweeg en daartussen kies. In Beckett se Waiting for (jodot is die konfrontasie tydens sluiting egter tussen die karakters se gedeelde perspektief en dié van die didaskalia:

Vladimir: Well? Shall we go?

Estragon: Yes, let's go.

They do not move

(Beckett, 1965:94).

Danksy die leë plek aan die einde van die teks word die leser met die keuse tussen die perspektief van die karakters en die didaskalia gelaat: gaan die karakters se situasie verander, of nie?

In die terne van die genremodel waannee ek werk, verskil die dramagenre in dié opsig van onderskeidelik die narratief en die poësie. As aanvaar word dat die narratiewe sisteem aan die hand van 'n tydruimtelike kontinuum vir die leser die 
kognitiewe funksie van geskiedenis demonstreer, en die primêre organisasiebeginsel van dié demonstrasie historiese kousaliteit is (Strydom, 1996), sal die narratief gekenmerk word deur die afhandeling en die afsluiting van die narratiewe verloop, dit wil sê deur 'n geslote einde. Volgens Ricoeur (1981:174) word die leser gerig deur die opeenvolgende verloop van handeling, gedagtes en gevoelens:

By this I mean we are pushed ahead by this development and that we reply to its impetus with expectations concerning the outcome and the completion of the entire process. In this sense, the story's conclusion is the pole of attraction of the entire development. (...) So rather than being predictable, a conclusion must be acceptable.

Sistemies beskou, gaan dit dus in die narratief oor die voltooiing van die narratiewe verloop, en gevolglik sal die narratiewe teks in beginsel 'n geslote einde hê.

Onderskeidend van die poësiesisteem is sy funksie om die leser te lei tot identifikasie met 'n gemoedstoestand (Strydom, 1996). Die poësiesisteem word daarom nie volgens die (logiese of historiese) kousaliteitsbeginsel georganiseer nie, maar volgens die beginsel van ekwivalensie:

In poetry the crucial question is not 'what happened?'; there is no chain of events and therefore no suspense based on the expectation of an outcome. Poetry in its epitome - the short lyric poem - involves rather a system of equivalent pieces of information expressed in various symbolic forms, the most characteristic of which is rhyme (Pomorska, 1985:171).

Aangesien die poësiegenre nie prinsipieel deur lineêre opeenvolging gekenmerk word nie, is 'n oop einde volgens Dresden (1980:39) nie moontlik nie: " $\mathrm{Er}$ bestaat geen open einde, omdat er in het geheel geen einde is. Ziet men af van de typografische beëindiging, dan blijkt al gauw dat door rijm bij voorbeeld of refrein of allerlei vormen van equivalenties één geheel is ontstaan dat noch begin noch einde kent maar uit totale afronding bestaat."

As sodanig verklaar logiese argumentasie waarom die drama wat optimaal funksioneer, in beginsel gekenmerk word deur 'n oop einde by wyse van 'n leë plek aan die tekseinde, en dat dit in dié opsig verskil van sluiting in die narratief en die poësie. Vervolgens, al is dit bloot inleidend, word die logika geverifieer, dit wil sê empiries ondersteun.

\section{Empiriese ondersoek}

Ter wille van objektiwiteit, dit wil sê om te verhoed dat ek, selfs onnadenkend, interpretasies maak wat my logiese argument geldig verklaar, analiseer ek enkele 
leesverslae van ander ondersoekers ten opsigte van drama-eindes tot steun of weerlegging van die voorafgaande teoretiese argument. Leesverslae word betrek wat dramas van verskillende periodes, dramatipes en nasionale literature interpreteer, aangesien die oortuigingspotensiaal van die logiese argument relatief is tot die aantal en verskeidenheid van empiriese voorbeelde.

\subsection{The Contest - M. Rugyendo}

In sy analise van The Contest in The Development of African Drama meen Etherton (1982:90) dat Rugyendo sy drama gebruik "to show the choice which is idealistically presented to the contemporary masses in Africa between socialist and capitalist forms of development". In The Contest ding twee jong mans, Hero 1 (seun van Mungwes) en Hero 2 (seun van Nkozis) mee om die hand van Maendeleo, 'n mooi jong meisie van die gemeenskap. Maendeleo verteenwoordig die massa in Afrika, terwyl Hero 1 en Hero 2 onderskeidelik Afrikakapitalisme en -sosialisme verteenwoordig. Van dié twee helde word verwag om konkrete argumente aan te voer waarin hulle uiteensit wat hulle voor en sedert onafhanklikheidswording gedoen het en wat toekomstige ontwikkeling sal behels in terme van hul onderskeie filosofiese perspektiewe. Die struktuur van The Contest is volgens Etherton (Etherton, 1982:96), "that of debate, and each of the two parties structures his own argument in the most convincing way possible".

Aan die einde van die drama word die ontvanger eksplisiet met dié botsende perspektiewe gekonfronteer: "For the argument is open-ended: it is the audience who decides in favour of one contestant over the other" (Etherton, 1982:90). Op grond van die keuse van die gehoor word die bruid aan Hero 1 of Hero 2 toegesê. 'n Leë plek met die funksie om die ontvanger voor 'n keuse tussen opponerende standpunte te stel, kom dus aan die einde van The Contest voor.

Die woordleegte aan die einde van dié drama is gestruktureer en dus betekenisvol; dit behels ' $n$ verbaal afwesige betekenaar aangesien die ontvanger self 'n keuse moet uitoefen tussen die onderskeie karakters se argumente; dit het 'n spesifieke plek op die sintagmatiese as, naamlik aan die einde van die teks; en danksy die leë plek se paradigmatiese strukturering kies die ontvanger of 'n sosialistiese of ' $n$ kapitalistiese filosofie.

\subsection{Der gute Mensch von Sezuan - B. Brecht}

In Brecht se Der gule Mensch von Sezuan word die funksie van drama, om die leser met die keuse tussen alternatiewe te konfronteer, uitgebuit en gesemantiseer om ideologiese kommentaar te lewer.

Der gute Mensch von Sezuan eindig met die gode wat op 'n pienk wolk hemel toe vlug, omdat hulle nie die konflik tussen hul etiese verantwoordelikheid en die 
vermoë om te oorleef in die wêreld kan oplos nie. Dié onopgeloste konflik word eksplisiet deur die spreker van die epiloog gestel:

You're thinking, aren't you, that this is no right

Conclusion to the play you've seen tonight?

We feel deflated too. We are nettled

To see the curtain come down and nothing settled.

Pfister (1988:97) beskryf die einde van dié drama as "an ending that, in failing to supply a resolution, delegates the responsibility for this to the audience". Hoewel die leser met die onopgeloste konflik gekonfronteer word, word hy deur die teks gelei om die woordleegte in te vul: "(The) audience, to whom the problem has been delegated, is not condemned to helplessness, but is invited, on the basis of implicit interpretative signals from the author, to criticise the system that has created this dilemma in the first place" (Pfister, 1988:97).

Die drama eindig met die onopgeloste konflik tussen twee standpunte, naamlik etiese verantwoordelikheid en oorlewing. Hoewel 'n narratiewe bemiddelingsfiguur die drama besluit (de-outomatiserend dus ten opsigte van die dramatiese sisteem), vestig hy die leser of toeskouer se aandag juis op die onopgeloste probleem. Die dramatiese funksie van die woordleegte om die leser met botsende alternatiewe te konfronteer, moet egter volgens Pfister veroordeel word; die leser moet die sisteem kritiseer wat hom konfronteer met die dilemma van 'n keuse tussen moontlikhede wat nie opponerend behoort te wees nie

Overgeset synde: Die woordleegte aan die einde van die teks is informatief omdat dit gestruktureer is en daarom voldoen dit aan die eerste voorwaarde vir 'n leë plek. In ooreenstemming met die daaropvolgende kriteria bestaan die leë plek uit 'n verbaal afwesige betekenaar wat struktureel aktief is en het die woordleegte 'n plek op die sintagmatiese as, naamlik aan die einde van die teks. Die leser kan nie sommer enige betekenis aan die lee plek toeken nie danksy paradigmatiese strukturering; die woordleegte kommunikeer 'n botsing tussen alternatiewe en word ingevul met kritiek teen die ideologiese sisteem wat die dilemma, die onopgeloste konflik, by die leser veroorsaak.

Die aanwesigheid van die woordleegte lei enersyds daartoe dat die leser self tussen die alternatiewe van etiese verantwoordelikheid en oorlewing moet kies, dit wil sê die leë plek het 'n dramatiese funksie, en andersyds vul die leser die woordleegte in met kritiek teen die sisteem, dit wil sê die leë plek funksioneer in terme van die ideologiese kode 


\subsection{The Taming of the Shrew - W. Shakespeare}

In 'n ondersoek na Shakespeare se komedies kom Howard (1986:114) tot die gevolgtrekking: dié dramas is "problem-posing structures that produce aesthetic experience marked as much by rupture and discontinuity as by the serene harmonization of contradictory elements". The Taming of the Shrew is 'n voorbeeld van 'n drama wat nie aan die leser een perspektief voorhou nie, maar "(...) sets for the audience the task of examining, by way of ongoing juxtaposition, two women who seem to sum up two competing cultural conceptions of the female" (Howard, 1986:115).

Aan die begin van die drama word twee botsende stereotipes aan die leser voorgehou: Bianca is mooi en saggeaard; Kate is 'n tierwyfie. Met verloop van die leesproses besef die leser egter dat albei karakteriserings te eensydig is en hersien moet word: Bianca mislei immers haar pa, verontagsaam haar man se wense en haar liefdestonele word gekenmerk deur oppervlakkige liefdesretoriek; op haar beurt protesteer Kate teen die uitbuiting van slawe en sy is lewendig en spitsvondig tydens haar liefdestonele. Die leser word dus voortdurend aangemoedig tot 'n herevaluering van die vertroude kulturele opvattings ten opsigte van die vrou.

Kate se verhouding met Petruchio verhoed egter dat die leser sy vroeëre romantisering van Bianca bloot vervang met die romantisering van die shrew. Die leser besef dat 'n verhouding gebaseer op selfsugtige eiewilligheid onbevredigend is en hy/sy moet self aflei dat 'n gebalanseerde man-vrouverhouding nóg op shrewish combat, nóg op misleidende vroomheid berus. Die handeling aan die einde van die drama sluit hierby aan as Kate en Petruchio eerder hulle sterk persoonlikhede saamspan en saam planne beraam, as om mekaar te ondermyn.

Dit is teen dié agtergrond wat die leser Kate se laaste spreekbeurt in die slot moet interpreteer. In dié spreekbeurt word die rol van man en vrou opgesom, word teenstrydighede - soos konformering teenoor indiwidualiteit, opregtheid teenoor die sosiale spel van voorgee - beklemtoon. Hoewel dié opposisies reeds inherent aanwesig is vanaf die begin van die drama, word dit telkens op die agtergrond geskuif. Hierdie teenstrydighede word voor die deur van die leser gelê wanneer hy/sy besef dat daar twee botsende interpretasiemoontlikhede vir Kate se slotwoorde is: of die leser kan Kate se spreekbeurt interpreteer as 'n kondonering van die sosiale voorskrifte (byvoorbeeld die vrou se onderdanige rol in 'n verhouding - dit waarteen sy vroeër rebelleer), óf die spreekbeurt het 'n ironiese en speclse strekking waarin Kate, vir haar eie gewin, slegs voorgee on die gehoorsame en onderdanige vrou te wees. 
Albei dié interpretasiemoontlikhede akkommodeer slegs gedeeltelik vroeëre teksinligting: die eerste moontlikheid reduseer Kate tot 'n naprater van clichés wat bots met haar vroeëre optrede, terwyl die tweede moontlikheid vaag is ten opsigte van Kate se eerlike opinie en boonop die voorafgaande onderskeid tussen haar en Bianca ophef, omdat albei dan voorgee ten einde hulself te bevoordeel. Dit is op grond van dié botsende keusemoontlikhede dat Howard (1986:118) opmerk: "Choose we must, but the very act of choice with which Kate's speech confronts us is one that makes us self-conscious about the contradictions that are embedded in the play" en "as we wrestle with the speech, trying to tame its potential to disrupt our desire for a perfectly harmonious conclusion, we are led not away from the problematic - but into it".

The Taming of the Shrew het dus 'n oop einde en eindig met 'n leë plek wat die leser met botsende alternatiewe konfronteer waartussen hy/sy self moet kies. Die leser moet self na afloop van die laaste spreekbeurt die opponerende moontlikhede verskaf, teenoor mekaar opweeg en 'n keuse mak. Verskillende karakters stel dus nie die opposisie in die slot nie, maar Kate se laaste spreekbeurt impliseer botsende alternatiewe.

Die woordleegte aan die einde van The Taming of the Shrew is gestruktureer en dus betekenisvol; dit veronderstel ' $n$ verbaal afwesige betekenaar aangesien die leser self die verskillende perspektiewe moet verwoord, opponeer en daarna 'n keuse uitoefen; dit kom aan die einde van die teks voor, dit wil sê dit is sintagmaties bepaald en danksy paradigmatiese strukturering word twee opposisies (Kate as bekeerde voorstaander van die konvensionele man-vrou-verhouding teenoor Kate as manipuleerder wat voorgee ten einde haar eie posisie te versterk) teenoor mekaar gestel.

\subsection{The Sea - E. Bond}

In "The Sea: anarchy as order" (Des Roches, 1987:480-495) analiseer Des Roches die verband tussen Bond se anargistiese filosofie en die struktuur van die drama. Wanneer die teks tematies oor anargie handel, maar struktureel berus op literêre konvensies, word die beginsel van anargie klaarblyklik ondermyn; "in these terms a play about anarchy is really a play about order" (Des Roches, 1987:481). Aangesien die drama egter strukturering van handeling veronderstel en afhanklik is van konvensies om betekenis te kommunikeer, kan die drama self nie anargisties wees nie. Die uitweg uit dié skaakmatposisie behels dat "if, instead of resolving inconsistencies and contradictions, Bond were to use them to affect a consciousness of collapse; and if instead of creating means to unify the structures which codify meaning, he were to create obstacles to closure; then we would begin to glimpse an image of anarchy" (Des Roches, 1987). The Sea word gekenmerk deur fragmentasie, en aangesien kousale relasies tussen tonele 
ondermyn word, stel dit Bond in staat om op indiwiduele tonele te fokus: "Through a series of isolated scenes, Bond "offers successive interconnected perceptions of the world, viewed socially and morally"' (Des Roches, 1987:483).

Teen dié agtergrond is die de-outomatisering van lesersverwagting in The Sea funksioneel. Hoewel die drama struktureel kenmerke van die komedie vertoon, is dit by wyse van "collapsing conventions which we take for granted, (that) Bond prohibits us from responding to the comedy automatically" (Des Roches, 1987:487). Ook die lesersverwagting ten opsigte van die slot van die komedie, "our desire for a happy ending" (Des Roches, 1987:484), word gedeoutomatiseer: "(Even) the last sentence of the play is uncharacteristically halting" (Des Roches, 1987:483).

Hoewel Willy en Rose by mekaar uitkom en saam die toekoms tegemoet gaan, is daar onsekerheid oor wat die toekoms vir hulle gaan inhou: "Willy's last, unfinished sentence, 'And I' $\mathrm{m}$ glad - ', is a poignant reminder that their uncertain future does not warrant the traditional celebration of a comic ending" (Des Roches, 1987:493). Soos die ander tradisionele kenmerke van die komedie is ook tekssluiting hier "presented too ambiguously to be interpreted automatically by the audience" (Des Roches, 1987:493).

Uit die analise blyk dat die onvoltooide slotsin betekenisvol is. Hoewel die verliefdes bymekaar is (in ooreenstemming met die komediekonvensie) kan die leser nie sonder meer 'n tradisioneel gelukkige toekoms vir die paartjie voorspel nie. Die leser ken betekenis aan die onvoltooide sin toe: die toekoms van die verliefdes is onseker en die leser moet self die alternatiewe van 'n gelukkige teenoor 'n ongelukkige toekoms voorsien en teenoor mekaar opweeg, dit wil sê die lee plek aan die einde van die teks funksioneer dramaties. Die leë plek aan die einde van die teks ondersteun ook op strukturele wyse die tematiese boodskap van anargie, aldus Des Roches (1978:481): "It is this stubborn refusal to yield gracefully to closure that interests me about The Sea, and prompts me to suggest that this play is not only ahout anarchy, but is itself anarchistic".

Die woordleegte aan die einde van The Sea voldoen aan die kriteria vir 'n leë plek soos vroeër geëkspliseer: die leë plek is betekenisvol want dit is as teken georden; dit bestaan uit 'n verbaal afwesige betekenaar (hier aangedui deur 'n grafiese teken, die aandagstreep) wat betekenis kommunikeer; dit kom aan die einde van die teks voor en is dus georden in terme van die sintagmatiese as; enersyds word dit ingevul met die alternatiewe van 'n gelukkige of ongelukkige toekoms vir die verliefdes, en andersyds ondermyn dit die tekskonvensies as gevolg van de-outomatisasie van die lesersverwagting ten opsigte van die komedie om só die verwerping van orde, anargie dus, te kommunikeer. 


\subsection{Six Characters in Search of an Author - L. Pirandello}

Volgens Liebler (1981:114) beroep sommige dramas - soos onder meer Pirandello se Six Characters - hul op die deelname van die ontvanger en is "the process of completion in the mind of the "reader/audience"". Só 'n oop einde konfronteer die onitvanger met 'n keuse en hy/sy "can and must choose to end the play for themselves" (Liebler, 1981:319).

In Six Characters kan twee vlakke onderskei word: eerstens, die dramatiese vlak met die spel tussen die "werklikheid" van die akteurs en die "fiksionaliteit" van die karakters; tweedens, die metadramatiese vlak wat die grens tussen die fiksionele wêreld van die akteurs en die ontvanger se werklikheid toets.

Albei dié vlakke word deur oop eindes gekenmerk. Aan die einde van die drama is die "verhoogbestuurder", na 'n dag se werk aan die storie van die karakters, self onseker oor die grens tussen sy "werklikheid" en die karakters se "fiksionele wêreld" as hy uitroep: "Pretence? Reality? To hell with it all! ... I've lost a whole day over these people, a whole day" (Liebler, 1981:318). Die dilemma van die verhoogbestuurder op die dramatiese vlak word implisiet geëggo op die meta-dramatiese vlak as ook die ontvanger onseker is ten opsigte van die onderskeid tussen fiksionaliteit en realiteit.

Die ontvanger word aan die einde van die drama met dieselfde keuse as die verhoogbestuurder gekonfronteer: wat is fiksioneel en wat is werklik? Die grens tussen kuns en werklikheid het op albei vlakke vervloei en nou word die ontvanger die taak gestel "(to) choose between illusions - between the illusion presented on stage and the illusion that we can construct a "reality" offstage more ordered than the one we have just witnessed on the stage" (Liebler, 1981:319). In Six Characters word dié botsende perspektiewe wat die ontvanger tydens tekssluiting konfronteer dus nie deur verskillende karakters aangebied nie. Die ontvanger moet self dié opposisies verwoord en teenoor mekaar stel, dit wil sê 'n leë plek kom aan die einde van die teks voor. Fiksionaliteit word teenoor realiteit gestel en die leser moet self besluit wat die aard van elk behels en dit teenoor mekaar opweeg, danksy die aanwesigheid van die woordleegte.

Dié leë plek wat die leser dwing om die grens tussen illusie en werklikheid te ondersoek, is betekenisvol omdat dit die resultaat van teksorganisasie is. Die leê plek bestaan uit ' $n$ verbaal afwesige betekenaar en die leser moet die opposisie tussen kuns en werklikheid self verwoord aan die einde van die teks, dit wil sê dit het 'n bepaalde plek op die sintagmatiese as. Vanweë paradigmatiese strukturering word die ontvanger gekonfronteer met die spesifieke opposisie fiksionaliteit teenoor realiteit. 


\section{Gevolgtrekking}

By wyse van logiese argument het ek verklaar waarom die drama in beginsel deur 'n oop einde - in besonder deur 'n lee plek - tydens tekssluiting gekenmerk word. Aan die hand van enkele leesverslae is dié argument empiries ondersteun. Indien 'n drama nie 'n oop einde het nie en nie met 'n leě plek sluit nie, eindig die drama nie dramaties nie, maar poëties of narratief. Daar moet in gedagte gehou word dat in 'n hterêre teks strategiee van die onderskeie genres voorkom en dat 'n teks nie generies suiwer is nie. Dit is dus danksy die aanwesigheid van verskillende genresisteme wat die dramateks 'n geslote einde kan hê en die gedigen verhaalteks op hul beurt dramaties kan sluit.

\section{Literatuurlys}

Beckett, Samuel. $1965^{2}$ Waiting for Godot. London : Faber \& Faber.

Corrigan, Robert W. 1984. The search for new endings: the theatre in search of a fix. Part III. Theatre Journal, 36(2):153-163.

Des Roches, Kay Unruh. 1987. The Sea. anarchy as order. Modern Drama, 30(4):480-495

Dresden, S. 1980 Het einde. Martinus Nijhoff: 's-Gravenhage.

Eco, Umberto. 1989. The open work. Translated by Anna Cancogni. Cambridge : Harvard University Press.

Etherton. 1982. The development of African drama New York : Africana Pub. Co

Forster, E.M. 1949. Aspects of the novel. London : Edward Morgan.

Gellrich, M. 1988. Tragedy and theory: the problem of conflict since Aristolle. Princeton Princeton University Press

Hawthorn, Jeremy. 1987. Unlocking the text: fundamental issues in literary theory. London : Edward Arnold.

Hillis Miller, J. 1978. The problematic of ending in narrative Nineteenth-Century Fiction, 33(1):3-7

Howard, Jean E. 1986. The difficulties of closure: an approach to the problematic in Shakespearian comedy. In: Braunmuller, A.R. \& Bulman, J.C. (eds.) Comedy from Shakespeare to Sheridan: change and contimuity in the English and European dramatic tradition. Newark: University of Delaware Press. p. 113-128

Kermode, F. 1979. The genesis of secrecy. Cambridge : Harvard University Press.

Liebler, Naomi C. 1981. "Give o'er the play": closure in Shakespeare's Hamlet and Pirandello's Six Characters in Search of an Author. Modern Drama, 24(3):314-322

Lodge, David 1981. Working with structuralism: essays and reviews on nineteenth-and twentieth-century literature. Boston : Routledge \& Kegan Paul

Miller, D.A 1989. Narrative and its discontents: problems of closure in the traditional novel. Princeton : Princeton University Press.

Pfister, Manfred. 1988. The theory and analysis of drama. Translated by John Halliday Cambridge : Cambridge University Press

Pomorska, Krystyna 1985 Poetics of prose In: Jakobson, Roman, Pomorska, Krystyna \& Rudy, Stephen (eds.) Verbal art, verbal sign, verbal time. Minneapolis : University of Minnesota Press. p 169-177.

Ricoeur, Paul. 1981 Narrative time In: Mitchell, W.J.T. (ed) On narrative. Chicago: The University of Chicago Press p. 165-186. 
Rowe, Joyce A. 1988. Equivocal endings in classic American novels. Cambridge Cambridge University Press

Schmidt, Henry J. 1992. How dramas end: essays on the German "Sturm und Drang", Büchner, Hauptmann, and Fleisser. Ann Arbor: The University of Michigan Press.

Serpieri, Alessandro. 1989. On the language of drama. Translated by Annamaria Carusi. Pretoria : University of South Africa.

Smith, Barbara Hermstein. 1968. Poetic closure: a study of how poems end Chicago: The University of Chicago Press.

Strydom, Leon. 1996. Genre distinction: a precondition for the scientific analysis of intertextuality. In: De Faria, Neide (ed.) Language and literature today: Proceedings of the XIXth Congress of the International Federation for Modern Languages and Literatures. Brasilia : UnB. p. 735-741.

Tarvin, William L. 1990. Tragic closure and "tragic calm". Modern Language Quarterly, 51(1):5-24.

Torgovnick, Marianna 1981. Closure in the novel. Princeton : Princeton University Press. 